\title{
REVIEW
}

\section{Development of cardiac conduction system in mammals with a focus on the anatomical, functional and medical/genetical aspects}

\author{
David Sedmera \\ Institute of Anatomy, First Faculty of Medicine, Charles University, Prague, and Institute of Animal Physiology \\ and Genetics, Academy of Sciences of the Czech Republic
}

Received $5^{\text {th }}$ April 2007.

Revised $17^{\text {th }}$ July 2007.

Published online $15^{\text {th }}$ August 2007.

\begin{abstract}
Summary
Recent progress in search of mechanisms regulating the spatio-temporal formation of specialized conduction tissues pushes us further in our understanding of the developmental molecular mechanisms of myocardial patterning. It is not clear which mechanisms direct the fates of chamber myocytes to differentiate into ventricular cardiac conduction system (CCS). Similarly, the formation and nature of connections between its most distal component, the Purkinje fibers, and the working myocytes, is unresolved. The process of remodelling of originally ring-like AV junction into AV node and accompanying fibrous insulation between the atria and ventricles is poorly understood, especially on the molecular level. Perturbation of this process can result in abnormal atrio-ventricular connections, manifesting as Wolf-Parkinson-White syndrome of ventricular pre-excitation. Understanding the signalling mechanisms involved in CCS development may be of significance to clinicians and basic researchers studying adult cardiac disease. Congenital abnormalities in CCS, as well as ectopic or inappropriate induction of CCS tissue in the mature heart, may be processes that contribute to, or cause, cardiac conduction disturbance and arrhythmia in adults. Understanding the signalling mechanisms that give rise to normal development of the CCS may thus provide insight into cardiac disease.
\end{abstract}

Keywords: myocyte - AV junction - Wolf-Parkinson-White syndrome - ventricular CCS - cardiac disease

David Sedmera, Institute of Animal Physiology and Genetics, Vídeňská 1083, 14220 Praha 4 Krč, Czech Republic

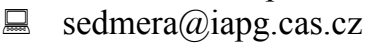

욜 +420267090588

圆 $\quad+420267090500$

\section{INTRODUCTION}

The cardiac conduction system (CCS) is vital for generating and synchronizing the heartbeat. Beginning with Tawara, Einthoven and other pioneering workers, a wealth of information has been collected over the last 100 years on the histologic, morphologic and physiologic characteristics of specialized cardiac tissues. 
However, in the last 10 years considerable effort has been put into understanding the cellular and molecular mechanisms governing development of the CCS (Pennisi et al. 2002, Gourdie et al. 2003). During this latter period, controversies have also arisen as to the nature of the signalling mechanisms involved in induction and patterning of the CCS, particularly with respect to the pathways functioning in mammals. In this review, I will try to summarize the current state of knowledge in this field and point out some of the remaining questions.

\section{Structure and function of the cardiac conduction system}

The layout of mammalian CCS is schematically depicted in Fig. 1. While subject to neuronal modulation, the intrinsic rhythm of the adult mammalian heart is determined within the tissues of the cardiac pacemaker — the sinuatrial (SA) node. The SA node is situated at the inflow port of the cardiac pump, or more formally, at the boundary of the superior caval vein and the right atrium. Following initiation of a cardiac action potential (AP) within the node, activation is propagated through the muscular tissues of the atria, eventually focusing into the atrioventricular (AV) node. As its name implies, the AV node is located at the junction of the atria and ventricles, and functions as part of a mechanism for generating a momentary delay in the propagation of AP. The principal role of this $\mathrm{AV}$ delay generator is to separate (and to some extent insulate) the activation of the atrial chambers from that of the ventricles. Following exit from the AV node, AP rapidly propagates along the His bundle and its distal branches, finally activating the ventricular chambers via a highly ramified network of Purkinje fibers (Fig. 1). Together, this fast conduction system of His-Purkinje tissues forms the last of the main elements of the CCS.

\section{Phylogenetic view on CCS}

The main components of CCS show remarkable evolutionary conservation. In the lower vertebrates, the site of pacemaking activity is located at the inflow end of the heart, the sinus venosus (Irisawa 1978). It is a thin-walled muscular chamber emptying into the atrium, easily demonstrable in fishes and frogs using Stannius ligatures. Instead of the AV node, the lower vertebrates have a muscular atrio-ventricular canal, which supports the AV valve(s) and slows down the propagation of the electrical impulse between the atrium and ventricle (Arbel et al. 1977). One special feature of this compartment is its connection to the ventricular myocardium. It does not form a direct myocardial continuity with the compact layer of the ventricular wall, but connects rather with the ventricular trabeculae (Sedmera et al. 2003a). This results in activation of the ventricular myocardium proceeding from the endocardium to epicardium, apex to base direction, which has been documented in the fish (Arbel et al. 1977, Sedmera et al. 2003a), amphibian (Dillon and Morad 1981, Sedmera et al. 2003a) and reptilian (Alanis et al. 1973, Christian and Grigg 1999) heart. A similar arrangement, i.e. muscular AV canal connecting to ventricular trabeculae, is found in embryonic avian and mammalian hearts, allowing for the onset of apexto-base ventricular activation prior to completion of fibrous insulation between the atria and ventricles (Wessels et al. 1996, Davis et al. 2001, Kolditz et al. 2007). So while a functional equivalent of the His-Purkinje system is present in all adult vertebrate hearts, in birds and mammals its differentiation goes a step further: there is fibrous insulation of the His bundle and its branches (Anderson and Ho 1998), which minimizes their contact with the surrounding working myocardium and helps to assure rapid impulse propagation through these cable-like structures. It was suggested recently that at least part of this insulation is due to immigrant cardiac neural crest cells (Nakamura et al. 2006, Gurjarpadhye et al. 2007). The arrangement of the most distal component, the Purkinje fibers, also shows considerable interspecies differences. While the subendocardial Purkinje fibers are a constant feature, in some species (chick, sheep, pig) there were also described intramural fibers, typically in the periarterial location (Gourdie et al. 1995). While their presence seems rather logical, the fact that they can not be found in all species could be explained by differences in the expression of markers used for their detection, since even their morphological features vary among species (Robb 1965).

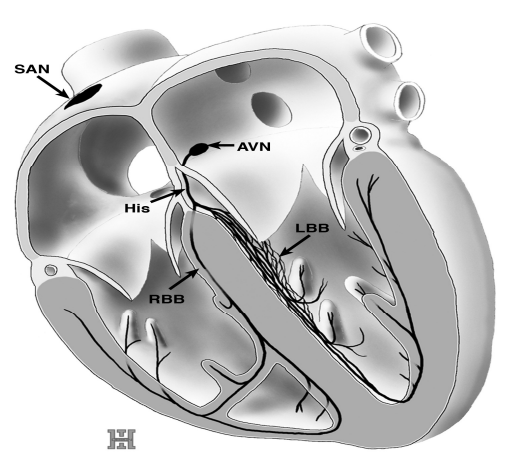

Fig. 1. Schematic representation of specialized conduction tissues of the human heart. SAN, sinoatrial node; AVN, atrioventricular node; His, His bundle; LBB, left bundle branch; RBB, right bundle branch. Art work by Ivan Helekal, Institute of Anatomy, Prague. 


\section{Functional development of CCS}

The development of a mature conduction system function during embryogenesis follows significant phases of cardiac morphogenesis (Gourdie et al. 2003). Initially, cardiac impulse propagates in a slow and apparently isotropic fashion from the sinus venosus, the most caudal portion of the tubular heart, toward the cranially located primitive outflow tract (Kamino 1991). While the apparent speed of impulse propagation gradually increases (based on total activation time inferred from isochronal epicardial maps), the sequence of ventricular activation as the heart loops follows the flow of blood (Chuck et al. 1997, Rentschler et al. 2002). Eventually, the immature base-to-apex sequence of ventricular activation undergoes an apparent reversal, altering to a mature apex-to-base pattern (Chuck et al. 1997, Rentschler et al. 2001, Reckova et al. 2003).

The first functional studies of developing conduction system were undertaken using unipolar electrodes (Arguello et al. 1986, de Jong et al. 1992, Chuck et al. 1997), followed by optical mapping with custom-designed photodiode arrays (Kamino 1991, Efimov et al. 2000, Litchenberg et al. 2000, Rothenberg et al. 2005) and later on, more conveniently, with high-speed CCD cameras. The functionality of CCS in the developing heart is best assessed using high-speed optical mapping of the ventricular activation sequence (Sedmera et al. 2005), a technique that has become widely used in recent years. Because of the focus of this review, I will compare the studies performed on mammalian species so far: mouse, rat, and rabbit. In the mouse, the function of His-Purkinje system is contained in the network of ventricular trabeculae, which express Cx40 (Coppen et al. 2003). The hallmark of its activity is the emergence of the apex-to-base activation pattern that is apparent already at ED10.5 (Rentschler et al. 2001). The first epicardial breakthrough of ventricular activation appears on the right side, consistent with earlier functionality of the right bundle branch versus left bundle branch. The left bundle branch functionality is evidenced by appearance of a second breakthrough near the left ventricular apex later on. This sequence of deployment was demonstrated also in the embryonic rat (Sedmera et al. 2005) and chick (Reckova et al. 2003). In embryonic rabbits, the apex-to-base activation was also detected at an early, pre-septation stage (ED11), but a complete developmental time line is not yet available (Rothenberg et al. 2005) in this popular electrophysiology model.

\section{Morphological and molecular markers of the CCS}

The appearance is species-specific (Robb 1965) and varies between different parts of the CCS. Generally, the specialized pacemaking and conduction tissues show lower expression of sarcomeric proteins, or their isoforms, different from the surrounding myocardium (Sanders et al. 1986, Lyons et al. 1990, Franco and Icardo 2001). Higher levels of glycogen are present, hinting at metabolical differences. The Purkinje cells are typically larger, and run in distinct strands under the endocardium or along the arteries. In contrast, nodal cells are less aligned and show a relative paucity of intercellular connections. Mammalian CCS cells also express the variety of markers found in neural tissues, such as acetylcholinesterase, neurofilament proteins, glial protein 120, HNK-1, or GIN2 (rev. Gorza et al. 1994)), which led some investigators in the past to consider it of neural crest origin (Gorza et al. 1988). While this hypothesis did not hold, neural crest cells are important for the neuronal modulation of CCS (Nakamura et al. 2006), and its ablation during embryogenesis resulted in morphological and functional anomalies of His bundle in the chick (Gurjarpadhye et al. 2007).

\section{Differential expression of connexins}

On the molecular level, proteins responsible for distinct physiological phenotypes serve as useful markers. As such, one of the most widely used is the combination of connexin (gap junction coupling proteins) expression. These patterns are speciesspecific, and each compartment has a distinct signature. In the mouse, the nodes express $\mathrm{Cx} 45$ and lack $\mathrm{Cx} 43$, which is the main connexin of the working atrial and ventricular myocardium. However, $\mathrm{Cx} 43$ is expressed abundantly in the rabbit AV node (Dobrzynski et al. 2007). Cx40 is expressed in the atrial, but not ventricular musculature, and also in the AV node, His bundle, and bundle branches. Distinction between the central (His bundle and its branches) and peripheral (Purkinje fibers) portion of the ventricular conduction system lies in the expression of $\mathrm{Cx} 43$, which is present only in the Purkinje fibers; the other two connexins (Cx40 and $\mathrm{Cx} 45)$ are present throughout (Coppen et al., 1999).

\section{Ion channels as physiological markers}

The electrophysiological properties of CCS cells are also determined by combination of ion channels expressed in their membrane; however, since the combination of isoforms used to achieve similar functional phenotype are largely species (and age) dependent, they are not widely used as markers. Furthermore, the biological function of the SA nodal pacemaker can be replicated by transgenic expression of the HCN1 channel in injected mesenchymal stem cells that couple to the myocytes to form pairs that generate the pacemaker current (Rosen et al. 2004). Similar functional and molecular evidence for involvement in pacemaking was reported for HCN4 (Liu et al. 2007, Viswanathan et al. 2007). During development, the 
conduction tissues differentiate rather early, so they can be distinguished from the surrounding working myocardium by their lack of proliferation activity (Thompson et al. 1990, Sedmera et al. 2003b). These mammalian studies match closely those performed in the chick model (Cheng et al. 1999).

Current views on the molecular cascades governing CCS patterning

\section{Transcription factors}

Information begins to emerge on the cascade of events resulting in the differential gene expression that distinguishes CCS from the working myocardium (Myers and Fishman 2004). SA node determination on the molecular level has been recently described (Mommersteeg et al. 2007) and consists of a combination of transcription factors Nkx2.5, Tbx3, and Pitx2c. Nkx2.5 in the atrial myocardium suppresses the pacemaker channel gene Hcn4 and T-box transcription factor Tbx3, thus enforcing a progressive restriction of their expression to the forming $N k x 2.5$-negative sinoatrial node and sinus horns and establishing a gene expression boundary between the atrium and SA node. Tbx3 in turn suppresses the chamber differentiation programme, providing an additional conscription mechanism. Deficiency on Tbx3 results in an expansion of the atrial gene expression program into the nodal area and a partial loss of nodal gene expression, whereas its overexpression reciprocally suppressed the atrial programme and induced pacemaking phenotype (Hoogaars et al. 2007). Pitx2c is a laterality determination gene that suppresses the programme for SA node formation on the left side, resulting in a right-sided position of the node.

Determination of the AV node is linked to formation of the AV canal in the developing heart, or rather, differentiation of the atrial and ventricular chambers from the "primitive" myocardium of the cardiac tube (Moorman et al. 1998, Moorman and Christoffels 2003). A combination of T-box transcription factors $T b \times 2$ and $T b x 5$ signalling is implicated (Moskowitz et al. 2004), with Tbx5 being the determinant of the AV canal and also the ventricular conduction system. Tbx2 is induced by BMP2 expression, and repressed by Hesr 1 expressed in the atrial and Hesr2 in the ventricular myocardium (Kokubo et al. 2007).

$N k \times 2.5$ signalling is critical not only in the early stages of cardiogenesis (Lyons et al. 1995) but is also required for the later stages of the ventricular conduction system formation, namely differentiation of the Purkinje fibers in birds (Jay et al. 2004, Harris et al. 2006) as well as formation of the AV node and bundle branches (Jay et al. 2004). Recently, a new transgenic mouse model in which GFP is expressed in place of $\mathrm{Cx} 40$ has been described (Miquerol et al. 2004). As was shown previously (Delorme et al., 1995), Cx40 labels the mammalian ventricular CCS throughout development. In the $C x 40-$ GFP mouse ventricle, all sites of endogenous $\mathrm{Cx} 40$ expression are highlighted by green fluorescence, enabling the unequivocal identification of ventricular CCS components (Fig. 2). These mice have been bred into an $N k x 2.5+/-$ background. In agreement with the previous reports on conduction system anomalies in $N k x 2.5$ heterozygotes (Jay et al. 2003, Jay et al. 2004), a reduction in the extent of Cx40expressing (i.e., GFP positive) CCS cells was observed in Cx40-GFP $N k x 2.5$ +/- mouse hearts. Optical mapping studies (Meysen et al. 2007) have indicated the occurrence of significant reductions in CCS conduction velocities in hearts from Cx40GFP $N k x 2.5+/-$ mice relative to $C x 40$-GFP $N k x-2.5$ $+/+$ (i.e., $N k x 2.5$ wildtype) littermates, thus providing morphological and functional proof of the Nkx2.5 requirement for ventricular CCS formation in mammals. This report also showed for the first time optical mapping data from the left bundle branch, a preparation previously suggested to be difficult to image in previous reports (Tamaddon et al. 2000). GFP expression can be in combination with other markers used to study the architecture of the conduction fascicles, as has been shown by an elegant and innovative study linking their conduction properties with strand direction and organization (van Veen et al. 2005). This valuable model can be used to rapidly assess CCS dysfunction in other transgenic mice deficient in the genes thought to play a role in its formation.

\section{Neuregulin/Endothelin signalling in ventricular CCS determination}

There has been recent interest in using the mouse as a model for probing CCS development mechanisms (Nygren et al. 2000, Christoffels et al. 2004, Jay et al. 2004, Moskowitz et al. 2004, Myers and Fishman 2004). As in the chick (Cheng et al. 1999), the origin of conduction cells in the mouse is cardiomyogenic (Meilhac et al. 2003, Sedmera et al. 2003b). However, the identity of the signals involved in the induction of specialized myocardial fate in mammals remain to be settled. The application of exogenous neuregulin (NRG) to embryonic cardiac explants of a transgenic mouse expressing $L a c Z$ in apparent association with the CCS was reported to convert myocytes to a conduction cell fate (Rentschler et al. 2002). However, conditional deletion of the NRG receptor ErbB2 does not appear to affect CCS structure and function (Ozcelik et al. 2002). The basis for this unexpected result is unclear, but may involve redundancy in components of the NRG signalling system in cardiac tissues.

In the chick, endothelin (ET) was identified as a secreted factor capable of turning on CCS markers in embryonic cardiomyocytes in vivo (Gourdie et al. 1998). This observation was later on 

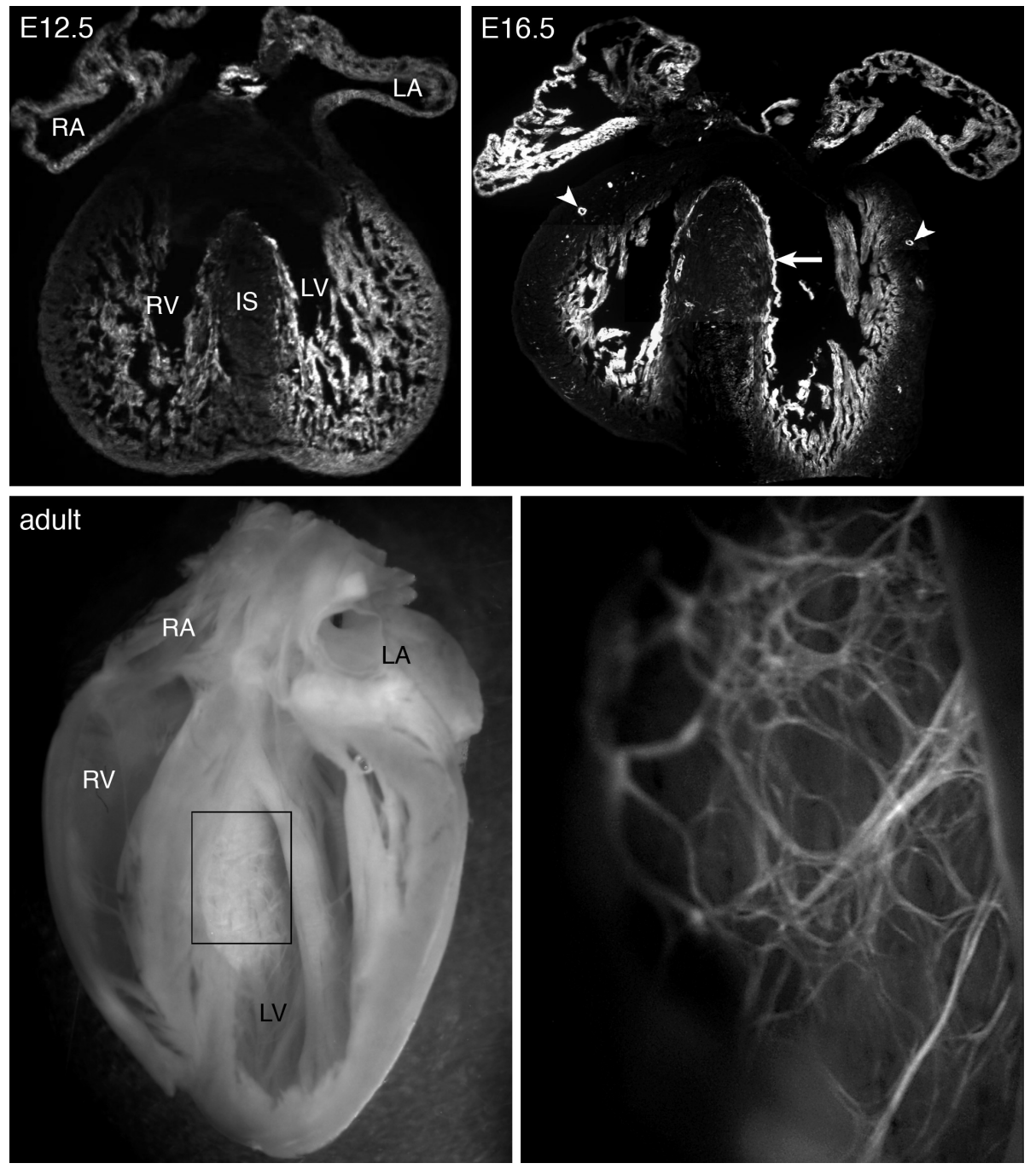

Fig. 2. Visualization of the ventricular conduction system in mouse with Cx40:GFP transgene. During development, the fast-conducting network is diffuse, and comprises all the trabeculae. Later on, left and right bundle branches (arrow) are found on both sides of the interventricular septum (IS), and the signal also appears in the coronary artery endothelium (arrowheads). The expression finally becomes restricted to the His bundle, its branches, and the subendocardial Purkinje network. Note its fine structure in the left ventricle (boxed area in the bottom left panel) identified by green fluorescence (bottom right panel). LA, left atrium, LV, left ventricle, RA, right atrium, RV, right ventricle. The top two panels were kindly provided by Sonia Meysen and Lucile Miquerol (IBDM, University of Marseilles).

confirmed in vivo, where overexpression of ET and endothelin converting enzyme (ECE) induced ectopic Purkinje fibers in the chick ventricle (Takebayashi-Suzuki et al. 2000). As with NRG, the situation is more complex in mammals, and redundancy is also a consideration in targeting ET1 signalling in vivo. There are, however, models for circumventing the redundancy in ET signaling pathways. Such models include the double knockout of ECE-1 and ECE-2, as well as the provocation of the phenotype in ET-1 knockout mouse by the administration of ET-signaling antagonists. Importantly, data from these knockout models indicate that profound loss of ET function results in primary myocardial phenotypes, including possible loss of structural elements of the CCS. The interpretation of the situation in mammals has been made more complex by two further recent studies. Gassanov and co-workers (Gassanov et al. 2004) have reported that exogenous ET-1 caused mouse embryonic stem cells to elicit action potentials consistent with the CCS phenotype. The ES-derived cells also showed upregulation of $C x 40$ and $C x 45$ in response to ET-1 (although not in response to NRG-1). These two gene products are exclusively expressed by CCS cells in ventricular myocardial lineages (Coppen et al. 1999). However, this in vitro study on stem cells used a limited set of 
markers, and might not fully reflect the complex interactions in vivo. Further, Patel and Kos (2005) have reported that treatment of ventricular myocytes isolated from E9.5 mouse embryos with either exogenous ET-1 or NRG-1 upregulates a battery of genes preferentially expressed in CCS tissues. Taken together, these studies suggest that ET-1 is also sufficient to promote CCS fate in mammals, confirming the evolutionary conservation of the responsiveness of embryonic myocytes to exogenous ET. However, whether endogenous ET or NRG signalling (or indeed interaction between these pathways) has a role in CCS development in vivo in mammals, or other vertebrate species, remains unknown.

\section{Conduction system and arrhythmias}

Abnormalities in CCS can occur for numerous reasons including congenital defects, ischemia or injury, or certain systemic diseases (Wolf and Berul 2006). There are many genes whose mutations could lead to conduction system anomalies from diverse groups: cardiac transcription factors, ion channels, gap junctions, energy metabolism enzymes and structural proteins. Defects in ion channel genes such as mutations in SCN5A can lead to tachyarrhythmias in humans as well as progressive degenerative disorders.

AV conduction defects such as heart block have received considerable clinical attention, and mutations in transcription factor $N k x 2.5$ as well as other genes, have been found to be associated with this condition (Benson 2004; Pashmforoush et al. 2004). In addition to conduction disturbances, morphological cardiac anomalies such as deficient atrial and ventricular septation or tetralogy of Fallot are also common in those patients (Benson et al. 1999). This connection was the first proven link between mutations in a gene expressed in the heart and human congenital heart disease.

In summary, recent progress in search of mechanisms regulating the spatio-temporal formation of specialized conduction tissues pushes us further in our understanding of the developmental molecular mechanisms of myocardial patterning. There are still many questions waiting to be answered. It is not clear which mechanisms direct the fates of chamber myocytes to differentiate into ventricular CCS. Similarly, the formation and nature of connections between its most distal component, the Purkinje fibers, and the working myocytes, is unresolved. The process of remodelling of originally ring-like $\mathrm{AV}$ junction into $\mathrm{AV}$ node and accompanying fibrous insulation between the atria and ventricles is poorly understood, especially on the molecular level. Perturbation of this process can result in abnormal atrio-ventricular connections, manifesting as Wolf-Parkinson-White syndrome of ventricular pre-excitation. In addition to developmental biologists, understanding the signalling mechanisms involved in CCS development may be of significance to clinicians and basic researchers studying adult cardiac disease. Congenital abnormalities in CCS, as well as ectopic or inappropriate induction of CCS tissue in the mature heart, may be processes that contribute to, or cause, cardiac conduction disturbance and arrhythmia in adults. Understanding the signalling mechanisms that give rise to normal development of the CCS may thus provide insight into cardiac disease.

\section{ACKNOWLEDGEMENTS}

The author's research is supported by VZ 206100-3 from the Ministry of Education of the Czech Republic, and AVOZ50450515 and Purkyně fellowship from the Academy of Sciences of the Czech Republic. I would like to thank Ivan Helekal for drawing Figure 1, and Sonia Meysen and Lucile Miquerol (IBDM, University of Marseilles) who produced the first two panels of Figure 2 and supplied the Cx40:GFP mice.

\section{REFERENCES}

Alanis J, Benitez D, Lopez E, Martinez-Palomo A: Impulse propagation through the cardiac junctional regions of the axolotl and the turtle. Jpn. J. Physiol. 23:149-164, 1973.

Anderson RH, Ho SY: The architecture of the sinus node, the atrioventricular conduction axis, and the internodal atrial myocardium. J. Cardiovasc. Electrophysiol. 9:1233-1248, 1998.

Arbel ER, Liberthson R, Langendorf R, Pick A, Lev M, Fishman AP: Electrophysiological and anatomical observations on the heart of the African lungfish. Am. J. Physiol. 232:H24H34, 1977.

Arguello C, Alanis J, Pantoja O, Valenzuela B: Electrophysiological and ultrastructural study of the atrioventricular canal during the development of the chick embryo. J. Mol. Cell. Cardiol. 18:499-510, 1986.

Benson DW, Silberbach GM, KavanaughMcHugh A, Cottrill C, Zhang Y, Riggs S, Smalls O, Johnson MC, Watson MS, Seidman JG, Seidman CE, Plowden J, Kugler JD: Mutations in the cardiac transcription factor NKX2.5 affect diverse cardiac developmental pathways. J. Clin. Invest. 104:1567-1573, 1999.

Benson DW: Genetics of atrioventricular conduction disease in humans. Anat. Rec. A 
Discov. Mol. Cell. Evol. Biol. 280:934-939, 2004.

Cheng G, Litchenberg WH, Cole GJ, Mikawa T, Thompson RP, Gourdie RG: Development of the cardiac conduction system involves recruitment within a multipotent cardiomyogenic lineage. Development 126:5041-5049, 1999.

Christian E, Grigg GC: Electrical activation of the ventricular myocardium of the crocodile Crocodylus johnstoni: a combined microscopic and electrophysiological study. Comp. Biochem. Physiol., Part A Mol. Integr. Physiol. 123:17-23, 1999.

Christoffels VM, Burch JB, Moorman AF: Architectural plan for the heart: Early patterning and delineation of the chambers and the nodes. Trends Cardiovasc. Med. 14:301307, 2004.

Chuck ET, Freeman DM, Watanabe M, Rosenbaum DS: Changing activation sequence in the embryonic chick heart. Implications for the development of the His-Purkinje system. Circ. Res. 81:470-476, 1997.

Coppen SR, Severs NJ, Gourdie RG: Connexin45 (alpha 6) expression delineates an extended conduction system in the embryonic and mature rodent heart. Dev. Genet. 24:82-90, 1999.

Coppen SR, Kaba RA, Halliday D, Dupont E, Skepper JN, Elneil S, Severs NJ: Comparison of connexin expression patterns in the developing mouse heart and human foetal heart. Mol. Cell. Biochem. 242:121-127, 2003.

Davis DL, Edwards AV, Juraszek AL, Phelps A, Wessels A, Burch JB: A GATA-6 gene heartregion-specific enhancer provides a novel means to mark and probe a discrete component of the mouse cardiac conduction system. Mech. Dev. 108:105-119, 2001.

de Jong F, Opthof T, Wilde AA, Janse MJ, Charles R, Lamers WH, Moorman AF: Persisting zones of slow impulse conduction in developing chicken hearts. Circ. Res. 71: 240-250, 1992.

Delorme B, Dahl E, Jarry-Guichard T, Marics I, Briand JP, Willecke K, Gros D, TheveniauRuissy M: Developmental regulation of connexin 40 gene expression in mouse heart correlates with the differentiation of the conduction system. Dev. Dyn. 204:358-371, 1995.

Dillon S, Morad M: A new laser scanning system for measuring action potential propagation in the heart. Science 214:453-456, 1981.

Dobrzynski H, Boyett MR, Anderson RH: New insights into pacemaker activity: promoting understanding of sick sinus syndrome. Circulation 115:1921-1932, 2007.

Efimov IR, Aguel F, Cheng Y, Wollenzier B, Trayanova N: Virtual electrode polarization in the far field: implications for external defibrillation. Am. J. Physiol. Heart Circ. Physiol. 279:H1055-H1070, 2007.

Franco D, Icardo JM: Molecular characterization of the ventricular conduction system in the developing mouse heart: topographical correlation in normal and congenitally malformed hearts. Cardiovasc. Res. 49:417429, 2001.

Gassanov N, Er F, Zagidullin N, Hoppe UC: Endothelin induces differentiation of ANPEGFP expressing embryonic stem cells towards a pacemaker phenotype. FASEB J. 18:1710-1712, 2004.

Gorza L, Schiaffino S, Vitadello M: Heart conduction system: a neural crest derivative? Brain Res. 457:360-366, 1988.

Gorza L, Vettore S, Vitadello M: Molecular and cellular diversity of heart conduction system myocytes. Trends Cardiovasc. Med. 4:153159, 1994.

Gourdie RG, Mima T, Thompson RP, Mikawa T: Terminal diversification of the myocyte lineage generates Purkinje fibers of the cardiac conduction system. Development 121:14231431, 1995.

Gourdie RG, Wei Y, Kim D, Klatt SC, Mikawa T: Endothelin-induced conversion of embryonic heart muscle cells into impulse-conducting Purkinje fibers. Proc. Natl. Acad. Sci. U.S.A. 95:6815-6818, 1998.

Gourdie RG, Harris BS, Bond J, Justus C, Hewett KW, O'Brien TX, Thompson RP, Sedmera D: Development of the cardiac pacemaking and conduction system. Birth Defects. Res. 69C:46-57, 2003.

Gurjarpadhye A, Hewett KW, Justus C, Wen X, Stadt H, Kirby ML, Sedmera D, Gourdie RG: Cardiac neural crest ablation inhibits compaction and electrical function of conduction system bundles. Am. J. Physiol. Heart Circ Physiol. 292:H1291-H1300, 2007.

Harris BS, Spruill L, Edmonson AM, Rackley MS, Benson DW, O'Brien TX, Gourdie RG: Differentiation of cardiac Purkinje fibers requires precise spatiotemporal regulation of Nkx2-5 expression. Dev. Dyn. 235:38-49, 2006.

Hoogaars WM, Engel A, Brons JF, Verkerk AO, de Lange FJ, Wong LY, Bakker ML, Clout DE, Wakker V, Barnett P, Ravesloot JH, Moorman AF, Verheijck EE, Christoffels VM: Tbx3 controls the sinoatrial node gene program and 
imposes pacemaker function on the atria. Genes Dev. 21:1098-1112, 2007.

Irisawa H: Comparative physiology of the cardiac pacemaker mechanism. Physiol. Rev. 58:461498, 1978.

Jay PY, Berul CI, Tanaka M, Ishii M, Kurachi Y, Izumo S: Cardiac conduction and arrhythmia: insights from $N k x 2.5$ mutations in mouse and humans. In Chadwick DJ, Goode J (eds.): Development of the Cardiac Conduction System. Wiley, Chicheter 2003, pp. 227-241.

Jay PY, Harris BS, Maguire CT, Buerger A, Wakimoto $\mathrm{H}$, Tanaka M, Kupershmidt S, Roden DM, Schultheiss TM, O'Brien TX, Gourdie RG, Berul CI, Izumo S: Nkx2-5 mutation causes anatomic hypoplasia of the cardiac conduction system. J. Clin. Invest. 113:1130-1137, 2004.

Kamino K: Optical approaches to ontogeny of electrical activity and related functional organization during early heart development. Physiol. Rev. 71:53-91, 1991.

Kokubo H, Tomita-Miyagawa S, Hamada Y, Saga Y: Hesr1 and Hesr2 regulate atrioventricular boundary formation in the developing heart through the repression of Tbx2. Development 134: 747-755, 2007.

Kolditz DP, Wijffels MC, Blom NA, van der Laarse A, Markwald RR, Schalij MJ, Gittenberger-de Groot AC: Persistence of functional atrioventricular accessory pathways in postseptated embryonic avian hearts: implications for morphogenesis and functional maturation of the cardiac conduction system. Circulation 115:17-26, 2007.

Litchenberg WH, Norman LW, Holwell AK, Martin KL, Hewett KW, Gourdie RG: The rate and anisotropy of impulse propagation in the postnatal terminal crest are correlated with remodeling of $\mathrm{Cx} 43$ gap junction pattern. Cardiovasc. Res. 45:379-387, 2000.

Liu J, Dobrzynski H, Yanni J, Boyett MR, Lei M: Organisation of the mouse sinoatrial node: structure and expression of HCN channels. Cardiovasc. Res. 73:729-738, 2007.

Lyons GE, Schiaffino S, Sassoon D, Barton P, Buckingham M: Developmental regulation of myosin gene expression in mouse cardiac muscle. J. Cell Biol. 111:2427-2436, 1990.

Lyons I, Parsons LM, Hartley L, Li R, Andrews JE, Robb L, Harvey RP: Myogenic and morphogenetic defects in the heart tubes of murine embryos lacking the homeo box gene Nkx2-5. Genes Dev. 9:1654-1666, 1995.

Meilhac SM, Kelly RG, Rocancourt D, EloyTrinquet S, Nicolas JF, Buckingham ME: A retrospective clonal analysis of the myocardium reveals two phases of clonal growth in the developing mouse heart. Development 130:3877-3889, 2003.

Meysen S, Marger L, Hewett KW, Jarry-Guichard T, Agarkova I, Chauvin JP, Perriard JC, Izumo S, Gourdie RG, Mangoni ME, Nargeot $\mathrm{J}$, Gros D, Miquerol L: $N k x 2.5$ cellautonomous gene function is required for the postnatal formation of the peripheral ventricular conduction system. Dev. Biol. 303: 740-753, 2007.

Miquerol L, Meysen S, Mangoni M, Bois P, van Rijen HV, Abran P, Jongsma H, Nargeot J, Gros D: Architectural and functional asymmetry of the His-Purkinje system of the murine heart. Cardiovasc. Res. 63:77-86 2004.

Mommersteeg MT, Hoogaars WM, Prall OW, de Gier-de Vries C, Wiese C, Clout DE, Papaioannou VE, Brown NA, Harvey RP, Moorman AF, Christoffels VM: Molecular pathway for the localized formation of the sinoatrial node. Circ. Res.100:354-362, 2007.

Moorman AF, de Jong F, Denyn MM, Lamers WH: Development of the cardiac conduction system. Circ. Res. 82:629-644, 1998.

Moorman AF, Christoffels VM: Cardiac chamber formation: development, genes, and evolution. Physiol. Rev. 83:1223-1267, 2003.

Moskowitz IP, Pizard A, Patel VV, Bruneau BG, Kim JB, Kupershmidt S, Roden D, Berul CI, Seidman CE, Seidman JG: The T-Box transcription factor Tbx5 is required for the patterning and maturation of the murine cardiac conduction system. Development 131: 4107-4116, 2004.

Myers DC, Fishman GI: Toward an understanding of the genetics of murine cardiac pacemaking and conduction system development. Anat. Rec. 280A:1018-1021, 2004.

Nakamura T, Colbert MC, Robbins J: Neural crest cells retain multipotential characteristics in the developing valves and label the cardiac conduction system. Circ. Res. 98:1547-1554, 2006.

Nygren A, Clark RB, Belke DD, Kondo C, Giles WR, Witkowski FX: Voltage-sensitive dye mapping of activation and conduction in adult mouse hearts. Ann. Biomed. Eng. 28:958-967, 2000.

Ozcelik C, Erdmann B, Pilz B, Wettschureck N, Britsch S, Hubner N, Chien KR, Birchmeier C, Garratt AN: Conditional mutation of the ErbB2 (HER2) receptor in cardiomyocytes leads to dilated cardiomyopathy. Proc. Natl. Acad. Sci. U.S.A. 99: 8880-8885, 2002.

Pashmforoush M, Lu JT, Chen H, Amand TS, Kondo R, Pradervand S, Evans SM, Clark B, Feramisco JR, Giles W, Ho SY, Benson DW, 
Silberbach M, Shou W, Chien KR: Nkx2-5 pathways and congenital heart disease; loss of ventricular myocyte lineage specification leads to progressive cardiomyopathy and complete heart block. Cell 117:373-386, 2004.

Patel R, Kos L: Endothelin-1 and Neuregulin-1 convert embryonic cardiomyocytes into cells of the conduction system in the mouse. Dev. Dyn. 233:20-28, 2005.

Pennisi DJ, Rentschler S, Gourdie RG, Fishman GI, Mikawa T: Induction and patterning of the cardiac conduction system. Int. J. Dev. Biol. 46:765-775 2002.

Reckova M, Rosengarten C, deAlmeida A, Stanley CP, Wessels A, Gourdie RG, Thompson RP, Sedmera D: Hemodynamics is a key epigenetic factor in development of the cardiac conduction system. Circ. Res. 93:7785, 2003.

Rentschler S, Vaidya DM, Tamaddon H, Degenhardt K, Sassoon D, Morley GE, Jalife J, Fishman GI: Visualization and functional characterization of the developing murine cardiac conduction system. Development 128 : 1785-1792, 2001.

Rentschler S, Zander J, Meyers K, France D, Levine R, Porter G, Rivkees SA, Morley GE, Fishman GI: Neuregulin-1 promotes formation of the murine cardiac conduction system. Proc. Natl. Acad. Sci. U.S.A. 99:1046410469, 2002.

Robb JS: Comparative Basic Cardiology. Grune \& Stratton, New York and London 1965.

Rosen MR, Robinson RB, Brink P, Cohen IS: Recreating the biological pacemaker. Anat. Rec. A Discov. Mol. Cell. Evol. Biol. 280: 1046-1052, 2004.

Rothenberg F, Nikolski V, Watanabe M, Efimov I.: Electrophysiology and anatomy of embryonic rabbit hearts before and after septation. Am. J. Physiol. Heart Circ. Physiol. 288:H344-H351, 2005.

Sanders E, de Groot IJ, Geerts WJ, de Jong F, van Horssen AA, Los JA, Moorman AF: The local expression of adult chicken heart myosins during development. II. Ventricular conducting tissue. Anat. Embryol. 174:187193, 1986.

Sedmera D, Reckova M, DeAlmeida A, Sedmerova M, Biermann M, Volejnik J, Sarre A, Raddatz E, McCarthy RA, Gourdie RG, Thompson RP: Functional and morphological evidence for a ventricular conduction system in the zebrafish and Xenopus heart. Am. J. Physiol. Heart Circ. Physiol. 284:H1152H1160, 2003a.

Sedmera D, Reckova M, DeAlmeida A, Coppen SR, Kubalak SW, Gourdie RG, Thompson RP: Spatiotemporal pattern of commitment to slowed proliferation in the embryonic mouse heart indicates progressive differentiation of the cardiac conduction system. Anat. Rec. 274A:773-777, 2003b.

Sedmera D, Reckova M, Rosengarten C, Torres MI, Gourdie RG, Thompson RP: Optical mapping of electrical activation in developing heart. Microsc. Microanal. 11:209-215, 2005.

Takebayashi-Suzuki K, Yanagisawa M, Gourdie RG, Kanzawa N, Mikawa T: In vivo induction of cardiac Purkinje fiber differentiation by coexpression of preproendothelin-1 and endothelin converting enzyme-1. Development 127:3523-3532, 2000.

Tamaddon HS, Vaidya D, Simon AM, Paul DL, Jalife J, Morley GE: High-resolution optical mapping of the right bundle branch in connexin40 knockout mice reveals slow conduction in the specialized conduction system. Circ. Res. 87:929-936, 2000.

Thompson RP, Lindroth JR, Allen AJ, Fazel AR: Cell differentiation birthdates in the embryonic rat heart. Ann. N.Y. Acad. Sci. 588: 446-448, 1990.

van Veen TA, van Rijen HV, van Kempen MJ, Miquerol L, Opthof T, Gros D, Vos MA, Jongsma HJ, de Bakker JM: Discontinuous conduction in mouse bundle branches is caused by bundle-branch architecture. Circulation 112:2235-2244, 2005.

Viswanathan S, Burch JB, Fishman GI, Moskowitz IP, Benson DW: Characterization of sinoatrial node in four conduction system marker mice. J. Mol. Cell. Cardiol. 42:946-953, 2007.

Wessels A, Markman MW, Vermeulen JL, Anderson RH, Moorman AF, Lamers WH: The development of the atrioventricular junction in the human heart. Circ. Res. 78: 110-117, 1996.

Wolf CM, Berul CI: Inherited conduction system abnormalities-one group of diseases, many genes. J. Cardiovasc. Electrophysiol. 17:446455, 2006. 